\title{
THE FINE GRINDING OF CORNCOBS TO USE AS A WATER ABSORPTION MATERIAL.
}

\section{H. H. Mohamed ${ }^{1}$ and M. I. Morsy ${ }^{2}$}

\section{ABSTRACT}

Corncobs wastes are considered to be one of the most environmental problems in Egypt. Grinding corncobs is the first step to solve this problem in order to be used as raw materials in several industries. Fine grinding of corncobs using a laboratory grinding mill (FML-100) was evaluated to use ground corncobs as an absorption material. The experiments were done by studying factors affecting machine performance (feed rate, grinding time and moisture content) on Fines degree, Machine productivity, Energy consumption, Water absorption, Compressibility Index, Hausner ratio, Surface area, Size reduction ratio, Grinding effectiveness and Bulk density of ground corncobs. Results showed that the maximum productivity was $12 \mathrm{~kg} / \mathrm{h}$ at a grinding time of 0.5 min, moisture content of $8 \%$ and feeding weight of $100 \mathrm{gm}$. The minimum energy consumption was $0.13(\mathrm{kWh} / \mathrm{kg})$ at the maximum productivity conditions. The highest water absorption for corncobs was $549.3 \%$ at particle size between 1 and $0.5 \mathrm{~mm}$, so it can be used as a high absorption material. The best operating condition was at the maximum productivity and the minimum energy consumption at grinding time of 0.5 min, moisture content of $8 \%$ and feeding weight $100 \mathrm{gm}$.

Keywords: Hammer mill, corncobs, fineness degree, surface area, size reduction.

\section{INTRODUCTION}

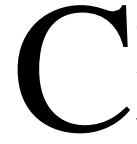

orncob is one of the most important agricultural wastes in Egypt, which is a byproduct of corn processing industry at the time of harvesting season. The production of corncobs was about $1,172.5$ thousand ton in 2016, which represent $15 \%$ of the total corn production of 7,817 thousand ton in Egypt (CAPMAS, 2018). Corncobs can be used as a source of energy forage for ruminant animals because it's low- quality coarse forage with a low protein content of $1.7 \%$, less palatable and contains high cellulose, hemicelluloses and lignin of 39.1, 42.1 and $9.1 \%$ respectively. (Guntoro et al. 2009).

1- Lecturer, Soil \& chem. Dept., Fac of Agric. Saba Basha, Alexandria University, Egypt.

2- Lecturer, Agric. \& Biosystems Eng. Dept., Fac. of Agric. El-Shatby, Alexandria University, Egypt. 
Gu et al., (2014) reported that corncobs became a renewable source of solid waste, which makes environmental problems.

Tampoebolon, (1996) reported that the physical treatment, chemical treatment, biological treatment or a combination of those treatments can be done to increase the quality of corncobs as ruminant animal's fodder by decreases crude fiber and increases crude protein.

Guntoro (2009) reported that corncobs are used as animal feed or returned to the harvested field as fertilizer. Morad et al. (2007) studied the efficiency of cutting machine during cutting some agriculture wastes such as rice straw, corncobs, and sugarcane in terms of the cutting lengths, energy and cost requirements. The highest efficiency was obtained at a rotating speed of $51.31 \mathrm{~m} / \mathrm{s}$, a feeding weightof $0.45 \mathrm{ton} / \mathrm{h}$ for sugarcane. Probst et al. (2013) studied the effect of moisture content from (10 to $20 \%$ ) on the behavior of ground corncobs. The productivity and the specific rate of corncobs breakage are decreased with the increase in moisture content. The efficiency of the hammer mill depends on particle size, moisture content, material properties, feed rate, and machine speed. (Mani et al., 2004; Manlu et al., 2003). The moisture content of the feed material is one of the most important factors affects corncobs grinding. Increasing the moisture content of the feed material increased energy consumption and decreased flow ability. (Fitzpatrick et al., 2004)

Singh et al. (2017) determined a new low-cost filtration method for waste water using corncobs as filter materials in its various forms. Corncobs are one of the most important agricultural wastes in maize cultivation. Corncobs are generally used in direct burning for energy production, which produces air pollution. Tsai et al. (2001) reported that adsorption using agriculture wastes consists of lignocelluloses that are a costeffective, eco-friendly and easy alternative in removing the heavy metals The objective of this work is to:

1- Determine the best factors affecting grinding corncobs.

2- Decrease energy consumption.

3-Determine the best particle size for maximum water absorption.

\section{MATERIALS AND METHODS}

This work was carried out by using a laboratory grinding mill (FML-100) in the laboratory of Soils and Agricultural chemistry dept., Faculty of 
Agriculture Saba Basha, Alexandria University. The experiments were conducted to evaluate the effect of feed rate, grinding time and moisture content on fineness degree, machine productivity, energy consumption, water absorption, compressibility index, hausner ratio, surface area, size reduction ratio, grinding effectiveness and bulk density of ground corncobs.

\subsection{Materials}

\subsubsection{Corncobs}

It is the central part of corn cobs, which is an agriculture waste produced after harvesting corn crop. Corncobs can be used as a fiber in fodder, soil conditioner, charcoal production, friendly rodenticide and produce chemical furfural. In this study, corncobs were obtained from the farm of the faculty of agriculture Saba Basha after harvesting corn crop. The main characteristics of corncobs were determined before being used in the study as shown in Tab. (1). The desired moisture levels of $(8,14$ and $18 \%$ ) were equipped by adding calculated amounts of water in samples and then putting in polyethylene bags. The samples were left in a refrigerator for 7 days at $5{ }^{\circ} \mathrm{C}$.

Table (1): Chemical characteristics of ground corncobs.

\begin{tabular}{ll}
\hline Characteristics & Corncob \\
\hline Total solids (\%w) & $88.95 \pm 1.29$ \\
Volatile solids (\%w) & $88.04 \pm 0.95$ \\
Hemicellulose (\%) & $34.23 \pm 1.31$ \\
Cellulose (\%) & $34.44 \pm 0.71$ \\
Lignin (\%) & $17.45 \pm 1.45$ \\
\hline
\end{tabular}

\subsubsection{Hammer grinding mill:}

A laboratory hammer grinding mill machine (FML-100) was used for milling corncobs as shown in Figs. (1 and 2).

The technical specifications of the machine are shown in Tab. (2).

\subsection{Instruments:}

A) An electronic balance (Sartorius AC211S) with a sensitivity of 0.0001 gm was used to determine the weight of the samples. 

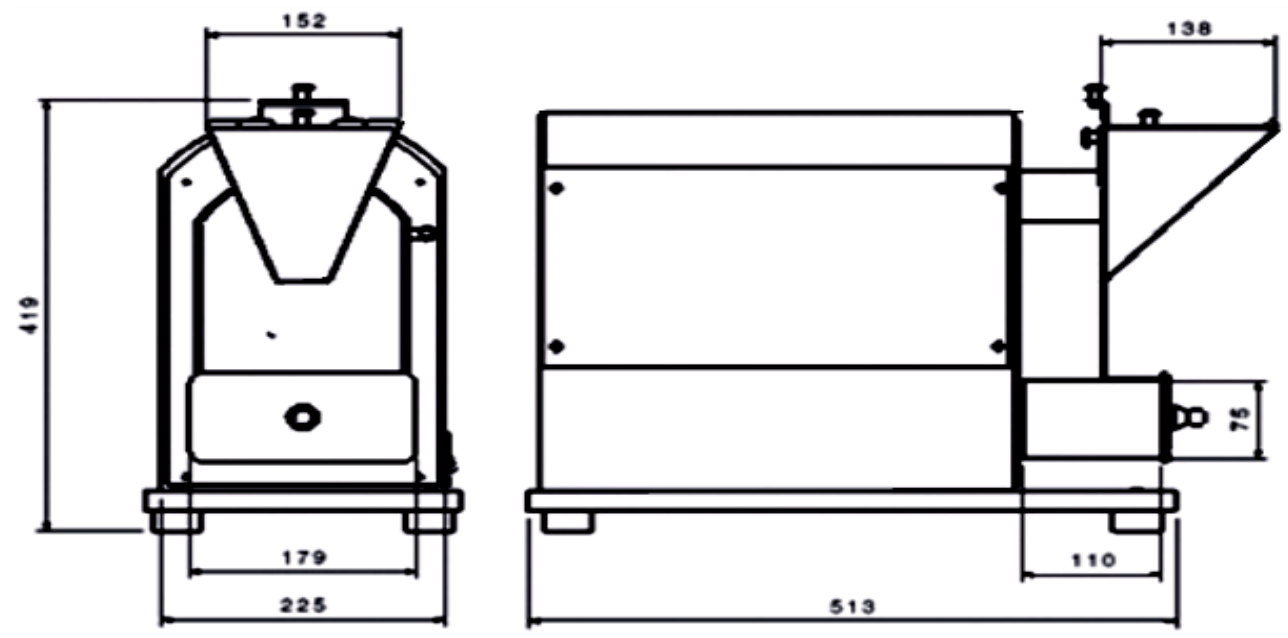

Fig.(1). Hammer grinding mill diagram (dimension in $\mathbf{m m}$ ).

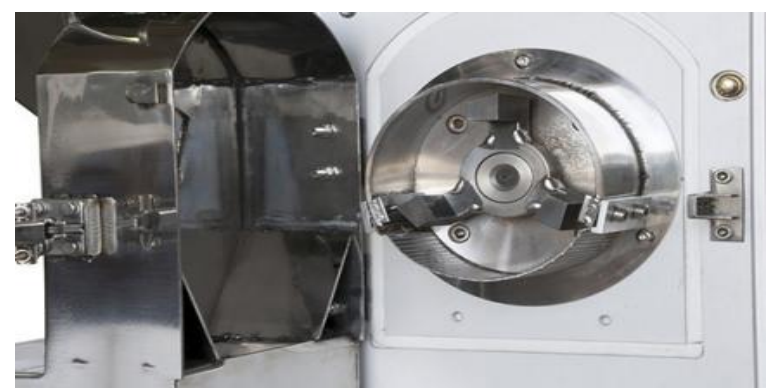

Fig.(2). Grinding chamber and blades for Hammer mill.

Table (2): Grinding mill specifications.

\begin{tabular}{|c|c|}
\hline Blades speed: & $3000 \mathrm{rpm}$ \\
\hline Grinding chamber volume & $565.2 \mathrm{~cm}^{3}$ \\
\hline Voltage & $220 \mathrm{~V}-50 / 60 \mathrm{~Hz}-5 \mathrm{~A}$ \\
\hline Power & $1.0 \mathrm{rW}$. \\
\hline Weight & $38 \mathrm{~kg}$. \\
\hline Grinding blades & Three stainless steel blades. \\
\hline Screen diameter & Round perforations $2.5 \mathrm{~mm}$ \\
\hline Blade width & $4 \mathrm{~cm}$ \\
\hline
\end{tabular}

B) An electric oven was used to dry samples at a temperature of $105^{\circ} \mathrm{C}$ for 24 hours.

C) The particle size distribution of ground Corncobs was determined by using of 2500, 2000, 1000 and $500 \mu \mathrm{m}$ sieves. The set of sieves was placed on a shaker for 10 minutes. The weights of particles retained on each sieve were measured. 
D) An image processing program (ImageJ) was used to display, analyze and process particles images. It can be used to study the effect of grinding process on dimensions, surface area and shapes of particles.

It supports standard image processing functions such as contrast manipulation, sharpening, smoothing, edge detection, and median filtering.

\section{2-3 Work plan:}

The experiments were conducted as follows:

1- A sufficient quantity of corncobs (about $3 \mathrm{~kg}$ ) was obtained from the farm of the faculty of agriculture Saba Basha.

2- Corncobs were crushed by hammer to small pieces about $(5 \mathrm{~cm}$ length and $1.5 \mathrm{~cm}$ width) to facilitate machine feeding.

3- The moisture content of corncobs was estimated by oven drying at 105 $\pm 1{ }^{\circ} \mathrm{C}$ for $24 \mathrm{~h}$ (Suthar and Das, 1996)

4- The desired moisture levels of $(8,14$ and 18\%) were equipped by adding calculated amounts of water in samples and then putting in polyethylene bags. The samples were left in a refrigerator for 7 day at $5{ }^{\circ} \mathrm{C}$.

5- Corncobs were divided into samples by weight of 25, 50, 75, 100, 150,200 and $300 \mathrm{~g}$ to evaluate the effect of feeding weight on grinding efficiency. Three grinding replications were conducted for each experiment.

6- Grinding times of $0.5,1,2$ and 3 minutes were used to evaluate the effect of grinding time on grinding efficiency.

\subsection{Methodology:}

\subsubsection{Evaluate Grinding Efficiency}

\section{A) Machine productivity}

Machine productivity is the measuring of a machine's ability in converting inputs into a final product using the following relationship:

$$
\mathbf{T}_{\mathbf{p}}=\frac{\mathbf{M}_{\mathbf{0}}}{\mathbf{T}}
$$

Where:

$\mathbf{T}_{\mathbf{p}}$ is productivity, $\mathrm{kg} \cdot \mathrm{h}^{-1}$.

$\mathbf{M}_{\mathbf{o}}$ is the mass of crushed corncobs, $\mathrm{kg}$.

$\mathbf{T}$ is grinding time, $\mathrm{h}$ 


\section{B) Size reduction ratio:}

The size reduction ratio is the ratio between corncobs size before and after grinding. The size reduction ratio was estimated according to Perry and Green (1984) as follows:

$$
\mathrm{Sr}=\frac{\mathbf{A c}}{\mathbf{A g}}
$$

Where:

$\mathrm{Sr}$ is the size reduction, times.

$\mathrm{Ac}$ is the average size of corncobs pieces before grinding, $\mathrm{cm}^{3}$.

$\mathrm{Ag}$ is the average size of corncobs particles after grinding, $\mathrm{cm}^{3}$.

\section{C) Grinding effectiveness:}

Grinding effectiveness is the ratio of final to initial corn cobs surface area. The grinding effectiveness was estimated according to Balasubramanian et al., (2011) as follows:

$$
\mathbf{G e}=\frac{\mathbf{S a}}{\mathrm{Sb}}
$$

Where:

Ge is Grinding effectiveness, \%.

$\mathrm{Sa}$ is the particles surface area after grinding, $\mathrm{cm}^{2}$

$\mathrm{Sb}$ is the pieces surface area before grinding, $\mathrm{cm}^{2}$

\subsubsection{Physical and flow property measurements:}

\section{A) Bulk and Tapped Densities}

The bulk density of corncobs was determined by measuring the weight and the volume of material in a filled cup of known volume, while tapped density was calculated after vibrate the sample using a sieve shaker at 900 vibrations per minute for $10 \mathrm{~min}$.

B) Compressibility Index and Hausner Ratio are two measures which can be used to determine the ability of a given powder sample to be compressed. The compressibility index (CI) was calculated according to (Zhou et al., 2008) as follows:

$$
C_{I}=\frac{T_{b d}-L_{b d}}{T_{b d}}
$$

Where:

$\mathbf{C}_{\mathbf{I}}$ is the compressibility index, $\%$.

$\mathrm{T}_{\mathrm{bd}}$ is the tapped bulk density, $\mathrm{kg} \cdot \mathrm{m}^{-3}$.

$\mathrm{L}_{\mathrm{bd}}$ is the loose bulk density, $\mathrm{kg} \cdot \mathrm{m}^{-3}$. 
The Hausner ratio (HR, dimensionless) was calculated as follows (Zhou et al., 2008):

$$
H_{r}=\frac{T_{b d}}{L_{b d}}
$$

\section{C) Mean weight diameter:}

The mean weight diameter was determined by classifying ground corncobs samples on the basis of modulus of fineness into five main grades starting from particle size less than $0.5 \mathrm{~mm}$ to larger than $2.5 \mathrm{~mm}$ as shown in fig. (3).

The total samples weight and the mass of each product categories were weighed. The distribution percent of each fraction was determined by dividing the fraction's mass with the total mass of the output product according to (Velu et al., 2006).

\begin{tabular}{|c|c|c|c|c|}
\hline 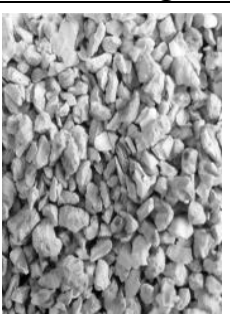 & 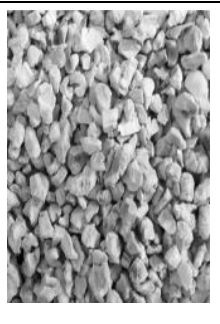 & 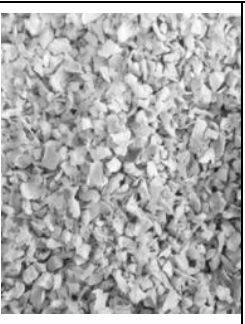 & 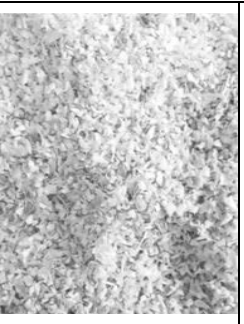 & 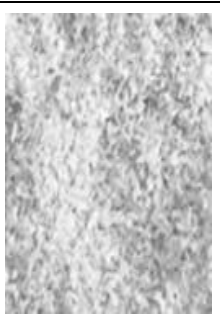 \\
\hline$(\mathrm{S}>2.5 \mathrm{~mm})$ & $(2<\mathrm{S}<2.5 \mathrm{~mm})$ & $(1<\mathrm{S}<2 \mathrm{~mm})$ & $(0.5<\mathrm{S}<1 \mathrm{~mm})$ & $(\mathrm{S}<0.5 \mathrm{~mm})$ \\
\hline
\end{tabular}

Fig. (3). The main grades of ground corncobs.

\subsubsection{Energy Calculation:}

The net power consumption for grinding corncobs was measured by using a digital multimeter (DT 9205A).

The electric current and voltage were measured to estimate machine power. The net power consumption for the grinding machine was calculated according to (Kurt, 1979) as follows:

$$
P_{c}=\frac{\sqrt{3} \cdot A \cdot V \cdot \varepsilon \cdot \cos \theta}{1000}
$$

\section{Where:}

$\mathrm{P}_{\mathrm{c}}$ is net power consumption, $\mathrm{kW}$

$\mathrm{A}$ is electric current, Amperes,

$\mathrm{V}$ is electrical voltage $(220 \mathrm{~V})$,

$E$ is mechanical efficiency (95\%),

$\operatorname{Cos} \theta$ is power factor $(85 \%)$ 
Therefore, the energy consumption, $\left(\frac{\mathrm{KW} \cdot \mathrm{h}}{\mathrm{kg}}\right)$ can be determined by dividing the net power consumption, $\mathrm{kW}$ by the machine productivity, $\frac{\mathrm{kg}}{\mathrm{h}}$.

\subsubsection{Water absorption test:}

Samples were dried at $105 \pm 5^{\circ} \mathrm{C}$ until a constant weight was achieved. Water absorption was determined according to the American Standard Testing Method ASTM (D-1037) as follows: dried samples were weighed. Dried samples were soaked in the water at room temperature for 24 hours. Wet samples were separated from water using funnel and filter paper as shown in fig. (4). Samples were left in the air to drain the water for one hour. Wet samples were weighed. The amount of water absorbed after 24 hours of soaking in water was calculated as follows:

$$
\mathrm{W}=\left(\frac{\mathrm{W}_{\mathrm{a}}-\mathrm{W}_{\mathrm{d}}}{\mathrm{W}_{\mathrm{d}}}\right) \times 100 \text {. }
$$

Where:

W: Water absorption, $\%$.

Wa: Weight of saturated sample in air, gm.

Wd: Specimen dry weight, gm.

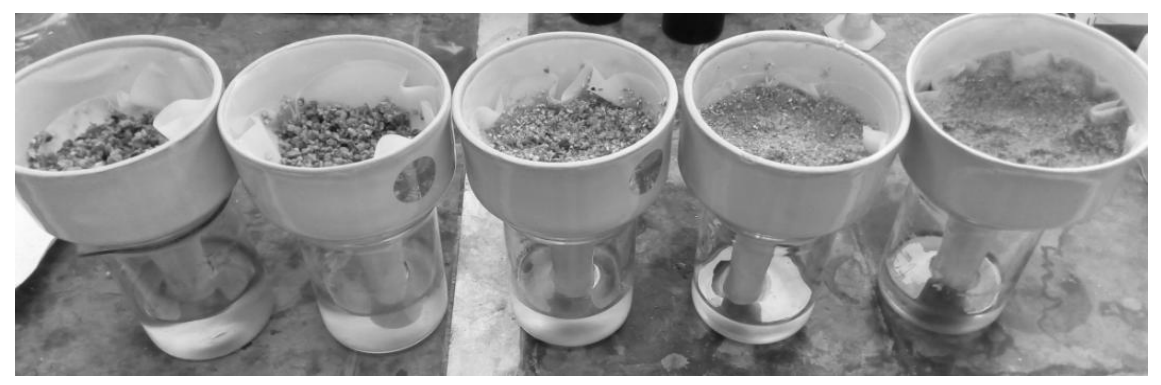

Fig. (4). Separating water from wet ground corncobs.

\section{RESULTS AND DISCUSSION}

\subsection{Factors affecting machine performance}

\subsubsection{Effect of feeding weight}

A- The effect of feeding weight by gram (ranged between 25 to $300 \mathrm{gm}$ ) on the particle size distribution of ground corncobs, $\%$ at different grinding times (from 0.5 to 3 minutes) and moisture content of $8 \%$ is shown in fig (5). In general, the graphs showed two stages, the first stage from 25 to $100 \mathrm{gm}$ and the second stage from 100 to $300 \mathrm{gm}$. 
At the first stage increasing feeding weight from 25 to $100 \mathrm{gm}$ resulted in a slight increase in the percent of particle size bigger than $2.5 \mathrm{~mm}$ and resulted in a slight decrease in the percent of particle size smaller than 2.5 $\mathrm{mm}$. This is due to a decrease in grinding quality by increasing feeding weight, so that big particles increase and small particles decrease.

At the second stage increasing feeding weight from 100 to $300 \mathrm{gm}$ resulted in a high increase in the percent of particle size bigger than 2.5 $\mathrm{mm}$, while resulted in a sharp decrease in the percent of particle size smaller than $2.5 \mathrm{~mm}$. This is due to the incomplete grinding of corncobs and the volume of input corncobs was bigger than the volume of the grinding chamber. The suitable feeding weight for this machine is at the first stage from 25 to $100 \mathrm{gm}$ to minimize the size of the particles $(0.5-$ $2.5 \mathrm{~mm})$.
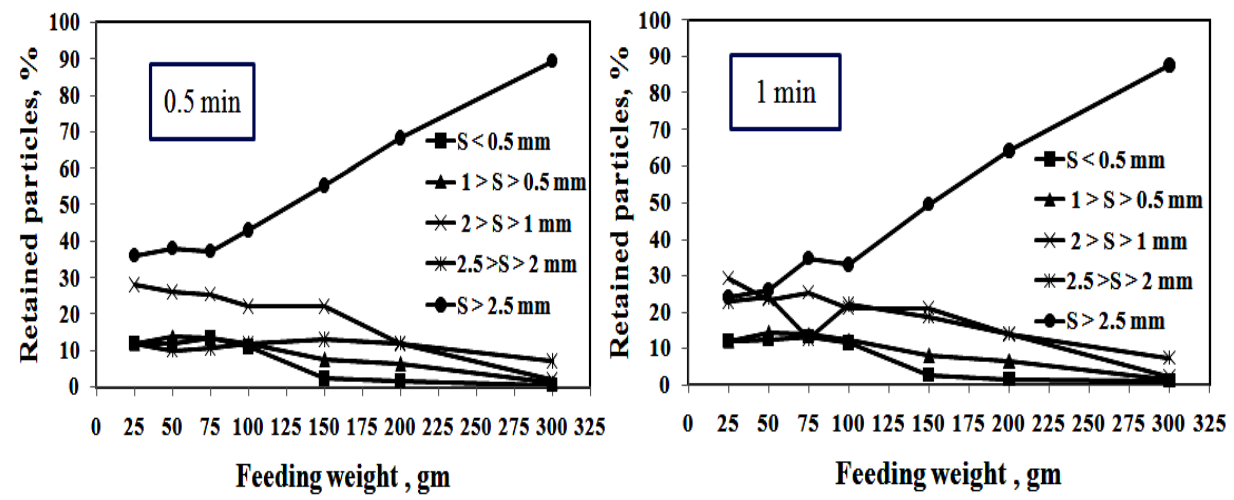

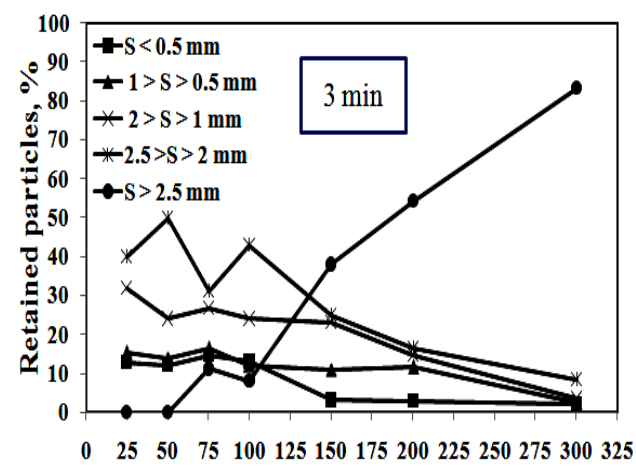

Feeding weight, gm

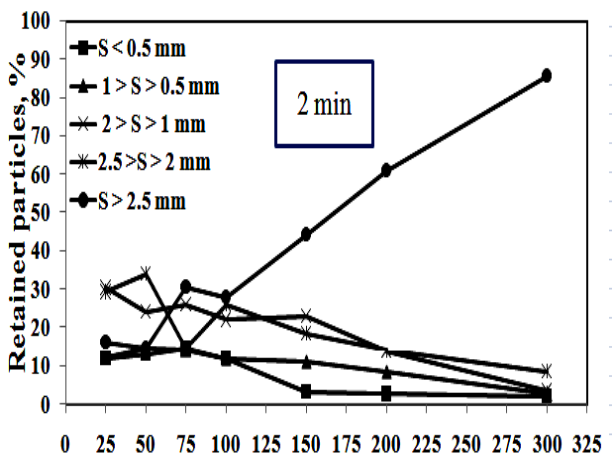

Feeding weight, gm

Fig. (5). Effect of feeding weight, gm on the particle size distribution, $\%$ at a moisture content of $8 \%$. 
B - The effect of feeding weight, gm on machine productivity, $\mathrm{kg} / \mathrm{h}$ and energy consumption, $\mathrm{kWh} / \mathrm{kg}$ at different grinding times, min and moisture content of $8 \%$ are shown in Figs. ( $~(7$ and $\vee$ ).

In general, the graphs showed that increasing feeding weight from 25 to $100 \mathrm{gm}$ resulted in increasing machine productivity, while resulted in decreasing energy consumption. The maximum productivity was $12 \mathrm{~kg} / \mathrm{h}$ at grinding time of $0.5 \mathrm{~min}$ and feeding weight of $100 \mathrm{gm}$, while the minimum productivity was $0.5 \mathrm{~kg} / \mathrm{h}$ at grinding time of $3 \mathrm{~min}$ and feeding weight of $25 \mathrm{gm}$. The minimum energy consumption was $0.13(\mathrm{kWh} / \mathrm{kg})$ at grinding time of $0.5 \mathrm{~min}$ and feeding weight of $100 \mathrm{gm}$, while the maximum energy consumption was $3.08(\mathrm{kWh} / \mathrm{kg})$ at grinding time of 3 min and feeding weight of $25 \mathrm{gm}$. The best operating condition was at the maximum productivity and the minimum energy consumption at grinding time of $0.5 \mathrm{~min}$ and feeding weight of $100 \mathrm{gm}$.

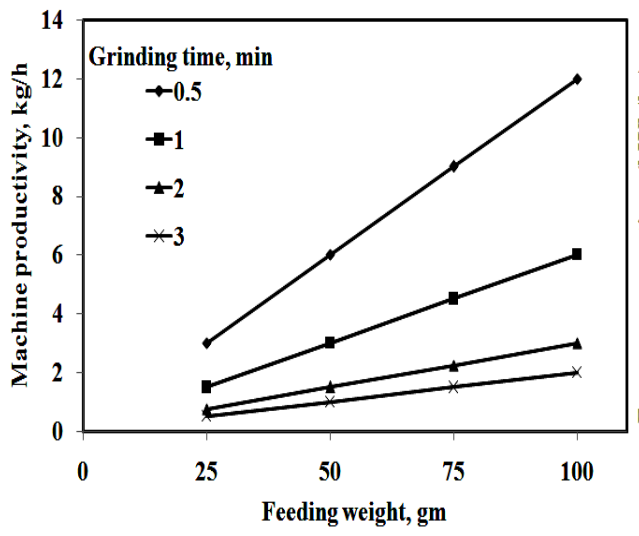

Fig. (6). Effect of feeding weight on machine productivity at different grinding times and moisture content of $8 \%$.

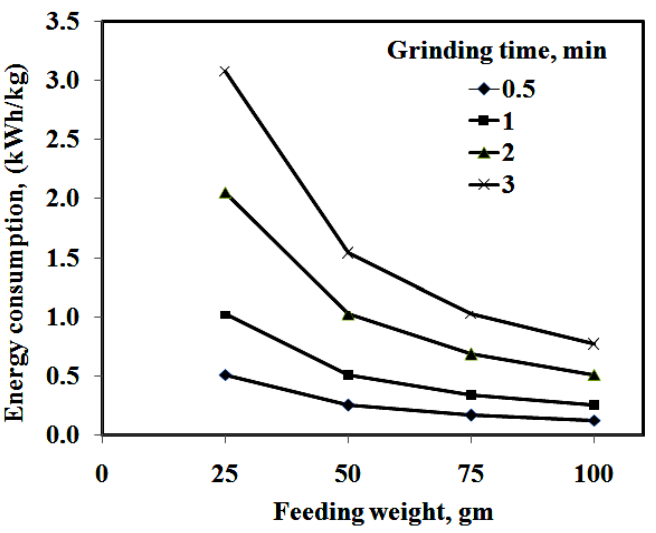

Fig. (7). Effect of feeding weight on energy consumption at different grinding times and moisture content of $8 \%$.

\subsubsection{Effect of grinding time:}

A- The effect of grinding time ( $\mathrm{min}$ ) on the particle size distribution of ground corncobs $(\%)$ at different feeding weights $(\mathrm{gm})$ and moisture content of $8 \%$ is shown in Fig. (8). In general, the graph showed that increasing grinding time from 0.5 to 3 minutes resulted in a sharp decrease, a high increase and a slight increase in the percent of particle size bigger than $2.5 \mathrm{~mm}$, between 2 and $2.5 \mathrm{~mm}$ and smaller than $2 \mathrm{~mm}$ respectively. Increasing grinding time from 0.5 to 3 minutes resulted in increasing the percent of particle size lower than $2.5 \mathrm{~mm}$. Increase 
grinding time for corncobs contributes to breaking up large particles into smaller particles. The best grinding time was 3 minutes to minimize the percent of particle size bigger than $2.5 \mathrm{~mm}$ and maximize the percent of particle size smaller than $2.5 \mathrm{~mm}$ for making a coarse powder $(0.5-2.5$ $\mathrm{mm})$.

B - The effect of grinding time $(\mathrm{min})$ on the machine productivity $(\mathrm{kg} / \mathrm{h})$ and the energy consumption $(\mathrm{kWh} / \mathrm{kg})$ at different feed rates $(\mathrm{gm})$ and moisture content of $8 \%$ are shown in Figs (9 and 10). In general, the graphs showed that increasing grinding time from 0.5 to 3 minutes resulted in a sharp decrease and a high increase in machine productivity and energy consumption respectively.

The best-operating conditions to maximize machine productivity and to minimize energy consumption were at the maximum feeding weight of $100 \mathrm{gm}$ and minimum grinding time of $0.5 \mathrm{~min}$.
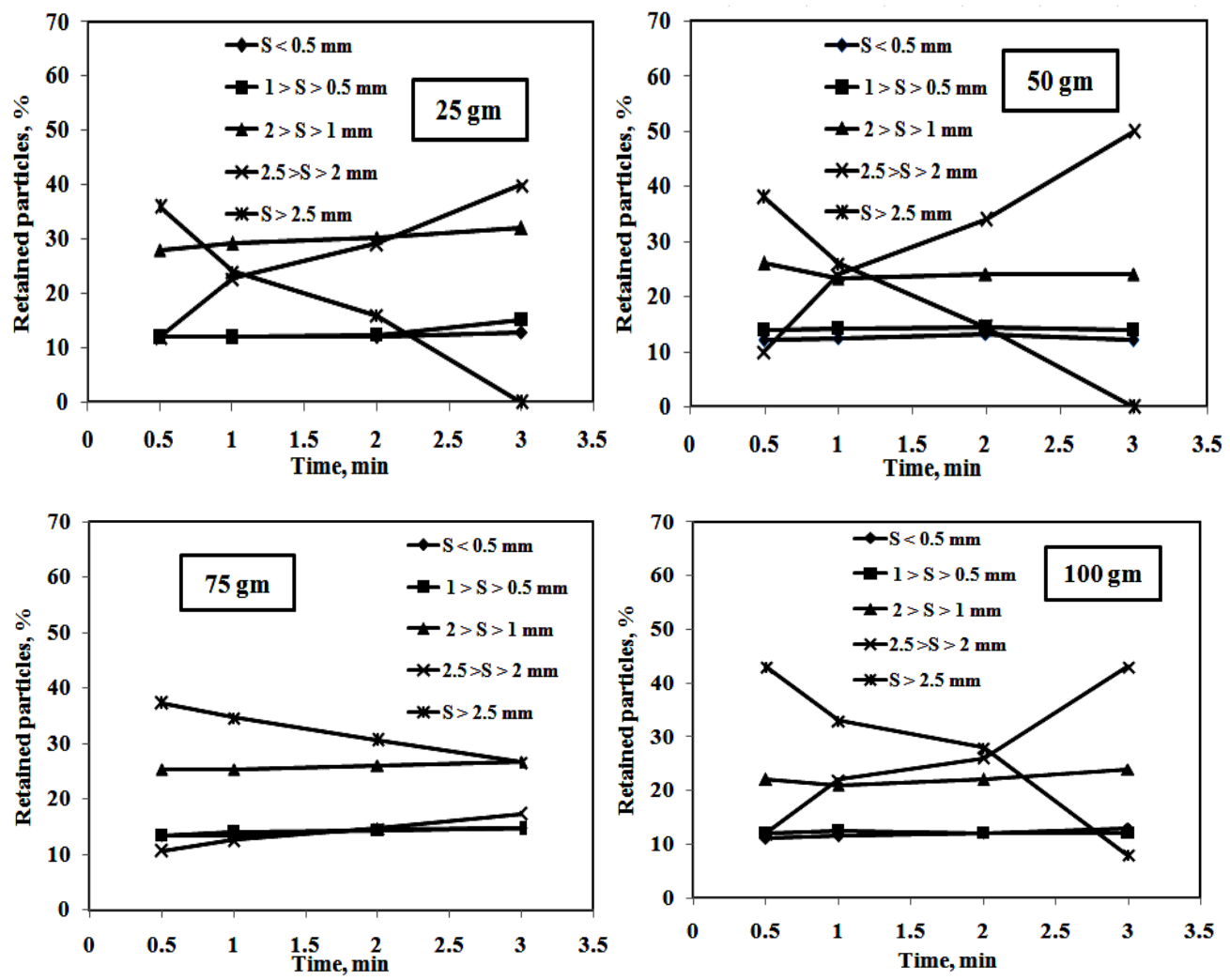

Fig. (8). Effect of grinding time, min on the particle size distribution of ground corn cobs, $\%$ at different feeding weights, gm and moisture content of $8 \%$. 


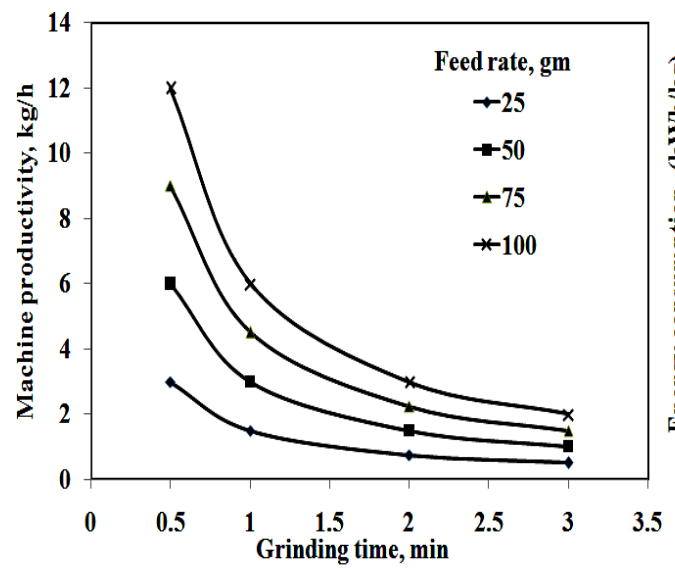

Fig. (9). Effect of grinding time on machine productivity at different feeding weights and moisture content of $8 \%$.

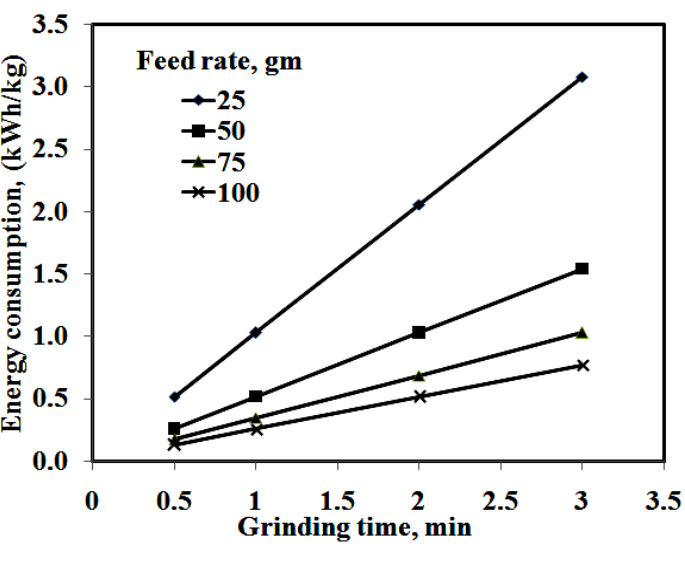

Fig. (10). Effect of grinding time on energy consumption at different feeding weights and moisture content of $8 \%$.

\subsubsection{Effect of moisture content}

The effect of moisture contents of 8,14 and $18 \%$ on the particle size distribution of ground corncobs (\%) at a feeding weight of $100 \mathrm{gm}$ and grinding times of $0.5,1,2$ and 3 minutes are shown in fig. (11). In general, the graph showed that increasing moisture contents from 8 to 18 $\%$ resulted in increasing the percent of particle size bigger than $2.5 \mathrm{~mm}$, while resulted in a slight decrease in the percent of particle size smaller than $2.5 \mathrm{~mm}$. Increasing corncobs moisture content resulted in increasing grinding resistance to transfer it to a coarse powder. Decreasing moisture content of corncobs decreases cobs elasticity, so it is easier to crashing low elasticity materials than high elasticity materials with high moisture content. The lowest moisture content of $8 \%$ is the best moisture content to minimize each of corncobs elasticity and crashing resistance.

\subsection{The ground quality}

\subsubsection{Bulk and tapped density:}

The effect of particle size of ground corncobs on the bulk and tapped density are shown in Fig.(12). and Tab.(2). It could be seen that increasing particle size resulted in increasing bulk and tapped density. The highest bulk and tapped densities were at particle size bigger than 2.5 $\mathrm{mm}$, while the lowest bulk and tapped densities were at particle size smaller than $0.5 \mathrm{~mm}$, which due to increasing the size of the particles 
results in an increase the weight and space between particles. The tapped particles decrease the space between particles so that tapped density is higher than bulk density.
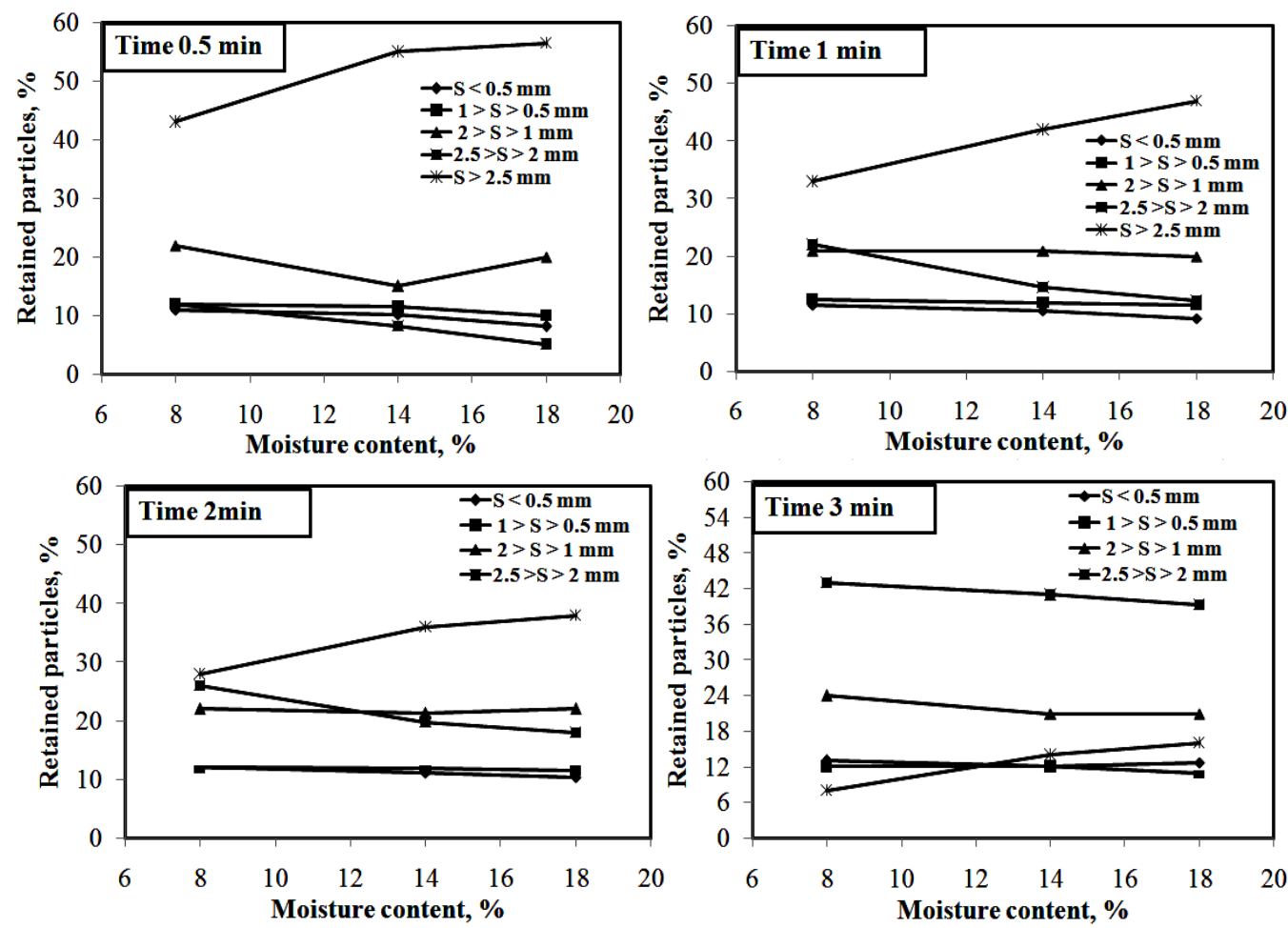

Fig. (11). Effect of moisture content, $\%$ on the particle size distribution, $\%$ at different grinding times.

Table (2): Physical and flow property of ground corncobs.

\begin{tabular}{|c|c|c|c|c|c|c|c|c|}
\hline Particles size & $\begin{array}{c}\text { Bulk density, } \\
\mathbf{K g} / \mathbf{m}^{\mathbf{3}}\end{array}$ & $\begin{array}{c}\text { Tapped density, } \\
\mathbf{K g} / \mathbf{m}^{\mathbf{3}}\end{array}$ & $\begin{array}{c}\text { Compressibilit } \\
\text { yindex, } \%\end{array}$ & Hausner ratio & $\begin{array}{c}\text { Size } \\
\text { reduction, time }\end{array}$ & $\begin{array}{c}\text { Water } \\
\text { apsorption, \% }\end{array}$ & $\begin{array}{c}\text { Surface area, } \\
\mathbf{c m}^{2} / \mathbf{g m}\end{array}$ & $\begin{array}{c}\text { Grinding } \\
\text { effectiveness }\end{array}$ \\
\hline $\mathbf{S}<\mathbf{0 . 5} \mathbf{m m}$ & 192.90 & 233.82 & 0.18 & 1.21 & 1.28 & 530.30 & 202.36 & 45.87 \\
\hline $\mathbf{1}>\mathbf{S}>\mathbf{0 . 5} \mathbf{m m}$ & 170.90 & 189.89 & 0.10 & 1.11 & 1.13 & 549.30 & 120.60 & 27.34 \\
\hline $\mathbf{2}>\mathbf{S}>\mathbf{l m m}$ & 286.20 & 311.09 & 0.08 & 1.09 & 1.89 & 361.55 & 66.63 & 15.10 \\
\hline $\mathbf{2 . 5}>\mathbf{S}>\mathbf{2} \mathbf{~ m m}$ & 468.80 & 498.72 & 0.06 & 1.06 & 3.10 & 173.60 & 14.17 & 3.21 \\
\hline $\mathbf{S}>\mathbf{2 . 5} \mathbf{~ m m}$ & 523.30 & 545.10 & 0.04 & 1.04 & 3.46 & 154.00 & 8.67 & 1.97 \\
\hline
\end{tabular}

\subsubsection{Compressibility Index and Hausner Ratio:}

The effect of particle size of ground corn cobs on the compressibility index and Hausner ratio are shown in Fig. (13). and Table (2). It could be seen that increasing particle size resulted in decreasing the compressibility index and Hausner ratio. This is due to an increase in the 
bulk density of ground corncobs. The highest values for compressibility index and Hausner ratio were $0.18 \%$ and 1.21 respectively at particle size smaller than $0.5 \mathrm{~mm}$, while the lowest values were $0.04 \%$ and 1.04 respectively at particle size bigger than $2.5 \mathrm{~mm}$.

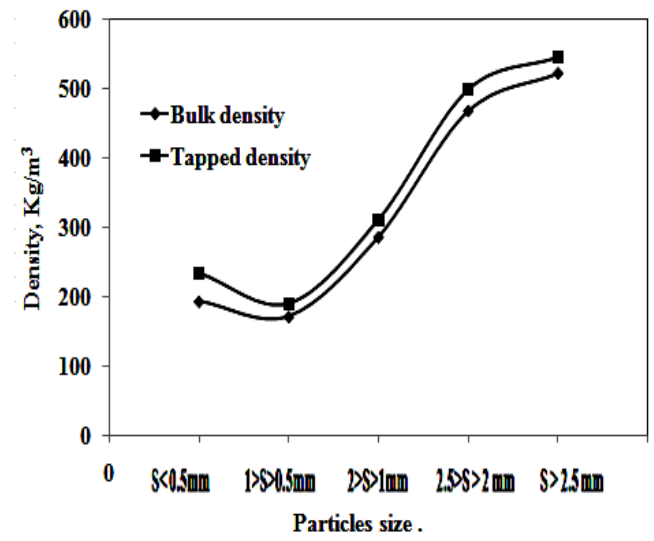

Fig. (12). Effect of particle size of ground Fig. (13). Compressibility index and Hausner ratio corncobs on the bulk and tapped density.

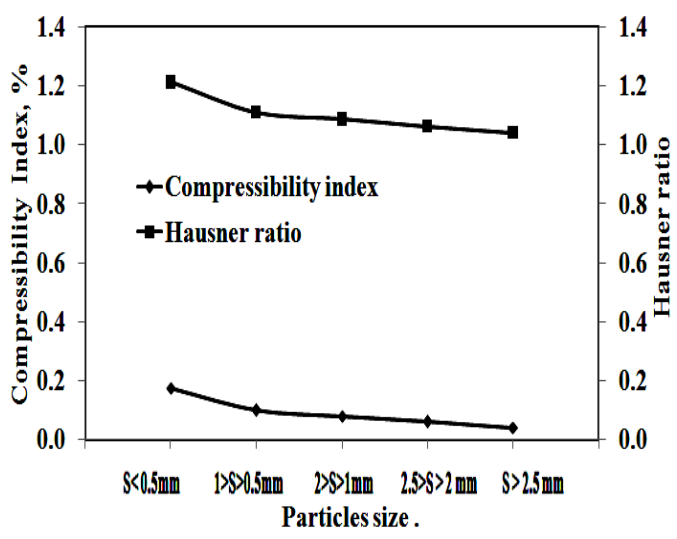

at different particle size of ground corncobs.

\subsubsection{Surface area and size reduction ratio}

The effect of particle size of ground corncobs on the surface area of one gram and size reduction ratio is shown in Fig (14). In general, increasing particle size from 0.5 to $2.5 \mathrm{~mm}$ resulted in decreasing surface area, while resulted in increasing size reduction ratio. The maximum surface area was $202\left(\mathrm{~cm}^{2} / \mathrm{gm}\right)$ at particle size smaller than $0.5 \mathrm{~mm}$, while the minimum surface area was $8.67\left(\mathrm{~cm}^{2} / \mathrm{gm}\right)$ at particle size bigger than $2.5 \mathrm{~mm}$. The maximum size reduction ratio was 3.46 times at particle size bigger than $2.5 \mathrm{~mm}$, while the minimum size reduction ratio was 1.13 at particle size smaller than $1 \mathrm{~mm}$.

\subsubsection{Grinding effectiveness}

The effect of particle size of ground corncobs on grinding effectiveness is shown in fig (15). In general, increasing particle size from 0.5 to $2.5 \mathrm{~mm}$ resulted in decreasing grinding effectiveness. The maximum grinding effectiveness was 45.86 at particle size smaller than $0.5 \mathrm{~mm}$, while the minimum grinding effectiveness was 1.96 at particle size bigger than 2.5 $\mathrm{mm}$. So it is important to maximize grinding effectiveness to minimize particle size and produce a coarse powder. 


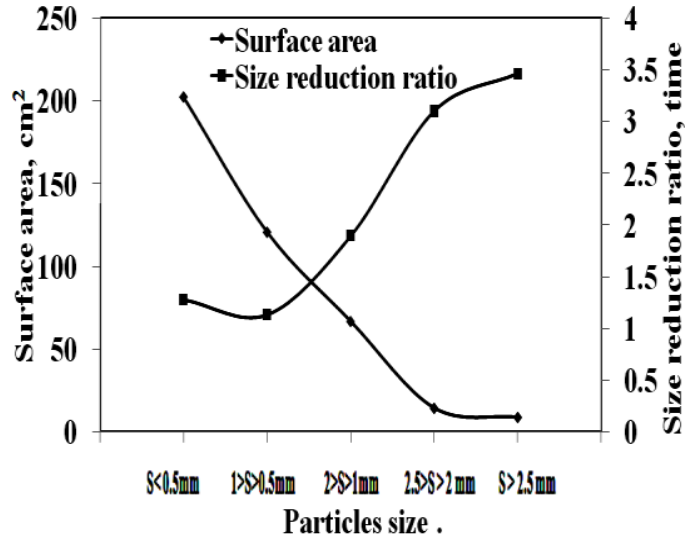

Fig. (14). Effect of particle size of ground corncobs on surface area and size reduction ratio.

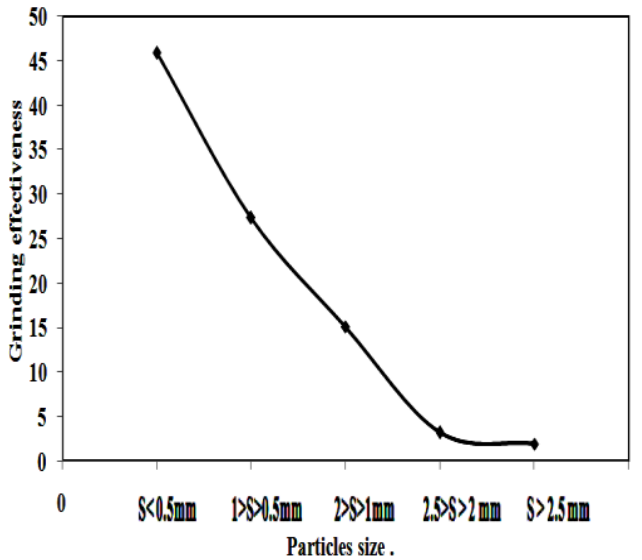

Fig. (15). Effect of particle size of ground corncobs on grinding effectiveness.

\subsubsection{Fineness degree of ground corncobs}

The particle size distribution of ground corncobs was classified into five grades $(\mathrm{S}<0.5 \mathrm{~mm}),(0.5<\mathrm{S}<1 \mathrm{~mm}),(1<\mathrm{S}<2 \mathrm{~mm}),(2<\mathrm{S}<2.5 \mathrm{~mm})$ and $(\mathrm{S}>2.5 \mathrm{~mm})$ as shown in fig (3). These grades were classified on the basis of modulus of fineness by calculating the percentage of each class as shown in Fig (16). Each grade was weighed and the percentage of each class was calculated. The particle size distribution of the five grades affected by three factors of feeding weight, grinding time and moisture content as noted before. The average values for the above mention grades were $12.63,13.31,25.58,23.77$ and $24.73 \%$ respectively.

The highest percent was at particle size $(1<\mathrm{S}<2 \mathrm{~mm})$, while the lowest percent was at particle size smaller than $0.5 \mathrm{~mm}$. The percent of fine particles smaller than $1 \mathrm{~mm}$ can be increased by increasing grinding time and decreasing each of feeding weight and moisture content but at the same time the energy consumption and the cost increase.

\subsubsection{Water absorption:}

The effect of particle size of ground corncobs on water absorption (\%) is shown in Fig (17). In general, water absorption increases by grinding corncobs into small particles. The maximum water absorption was $549.3 \%$ at particle size between 1 and $0.5 \mathrm{~mm}$, while the minimum water absorption was $154 \%$ at particle size bigger than $2.5 \mathrm{~mm}$. This is due to that, the maximum surface area was at particle size between 1 and 0.5 $\mathrm{mm}$. 

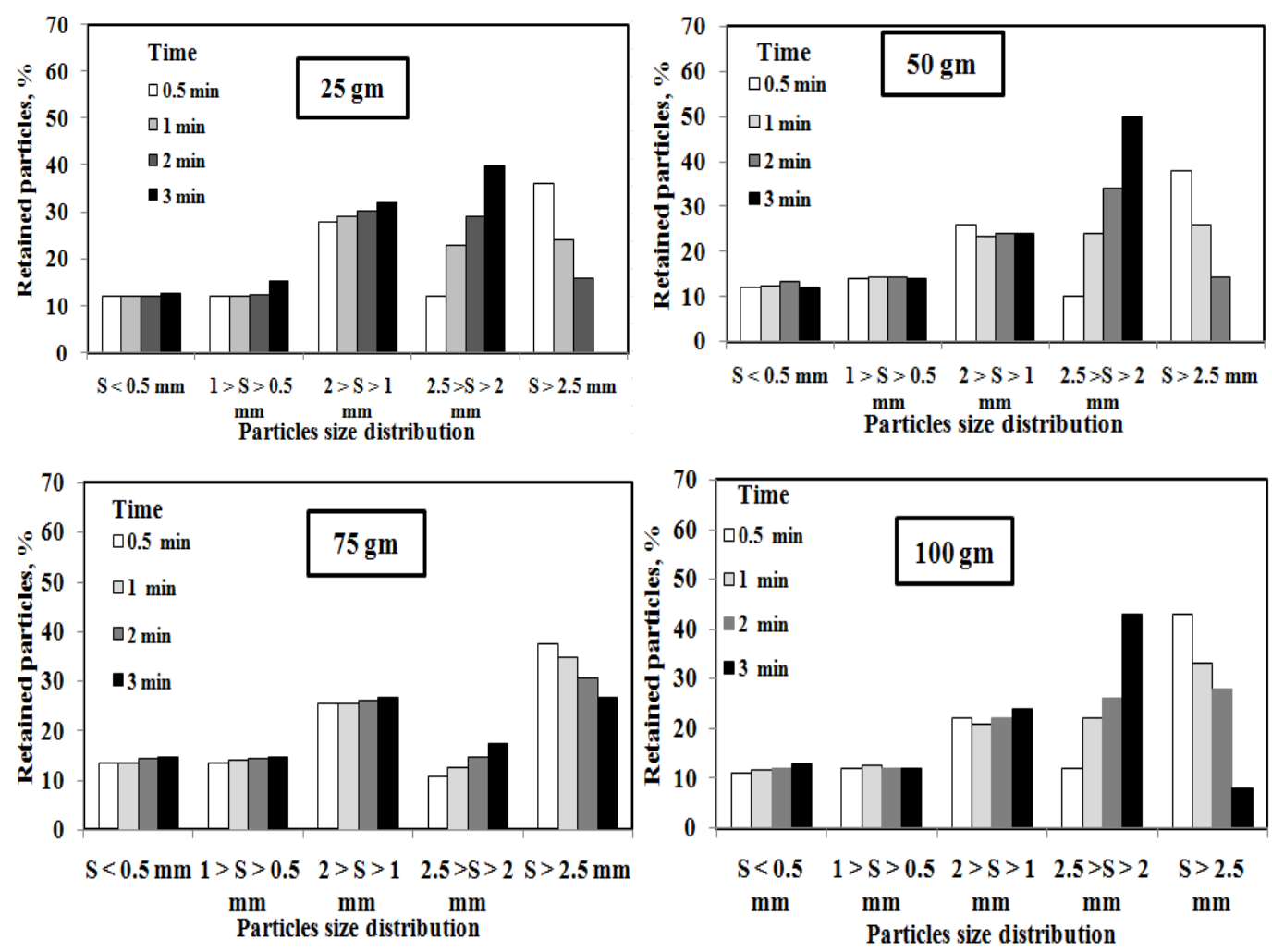

Fig. (16). The particle size distribution of ground corncobs.

The best particle size was between 1 and $0.5 \mathrm{~mm}$ to absorb the maximum percent of water to use ground corn cobs as water absorption materials. The relationship between surface area and each of water absorption and size reduction ratios are shown in fig (18). It was observed that increasing surface area from 8.62 to $202 \mathrm{~cm} 2$ resulted in increasing water absorption of corn cobs, while resulted in decreasing size reduction ratio. Two polynomial equations were determined to calculate water absorption and size reduction of ground corncobs according to surface area values.

The maximum water absorption and the minimum size reduction ratio were at the surface area of $120.6 \mathrm{~cm}^{2}$ at particle size between 1 and 0.5 $\mathrm{mm}$. The minimum water absorption and the maximum size reduction ratio were at the surface area of $8.67 \mathrm{~cm}^{2}$ at particle size bigger than 2.5 $\mathrm{mm}$. 

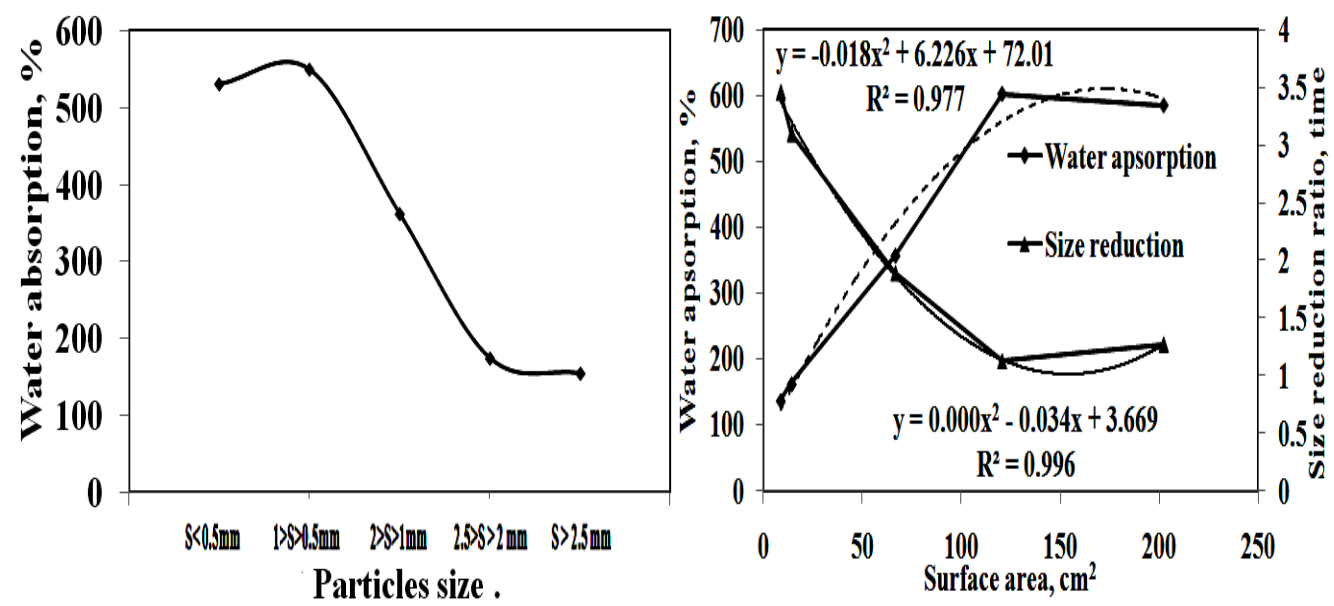

Fig. (17). Water absorption, \% of ground Fig. (18). Effect of surface area of ground corncobs corncobs at different particle size. on water absorption and size reduction ratio.

\section{CONCLUSIONS}

The effects of feed rate, grinding time and moisture content on the fine grinding behavior of corncobs were studied by measuring fineness degree, machine productivity, energy consumption and water absorption of ground corncobs. The particle size distribution of ground corncobs was classified into five grades from smaller than $0.5 \mathrm{~mm}$ to bigger than 2.5 $\mathrm{mm}$. The highest bulk and tapped densities were at particle size bigger than $2.5 \mathrm{~mm}$, while the lowest bulk and tapped densities were at particle size smaller than $0.5 \mathrm{~mm}$. The highest values for compressibility index and Hausner ratio were $0.18 \%$ and 1.21 respectively at particle size smaller than $0.5 \mathrm{~mm}$, while the lowest values were $0.04 \%$ and 1.04 respectively at particle size bigger than $2.5 \mathrm{~mm}$. The maximum surface area was $202\left(\mathrm{~cm}^{2} / \mathrm{gm}\right)$ at particle size smaller than $0.5 \mathrm{~mm}$, while the minimum surface area was $8.67\left(\mathrm{~cm}^{2} / \mathrm{gm}\right)$ at particle size bigger than 2.5 $\mathrm{mm}$. The maximum size reduction ratio was 3.46 times at particle size bigger than $2.5 \mathrm{~mm}$, while the minimum size reduction ratio was 1.13 at particle size smaller than $1 \mathrm{~mm}$. The maximum grinding effectiveness was 45.86 at particle size smaller than $0.5 \mathrm{~mm}$, while the minimum grinding effectiveness was 1.96 at particle size bigger than $2.5 \mathrm{~mm}$. The maximum water absorption was $549.3 \%$ at particle size between 1 and 0.5 $\mathrm{mm}$, while the minimum water absorption was $154 \%$ at particle size 
bigger than $2.5 \mathrm{~mm}$. According to the above mention results, particle size between 1 and $0.5 \mathrm{~mm}$ of ground corncobs is the best size to use as water absorption material.

The maximum productivity of $12 \mathrm{~kg} / \mathrm{h}$ and the minimum energy consumption of $0.13(\mathrm{kWh} / \mathrm{kg})$ were at grinding time of $0.5 \mathrm{~min}$ and feeding weightof $100 \mathrm{gm}$. The best operating condition was at the maximum productivity and the minimum energy consumption at grinding time of $0.5 \mathrm{~min}$, moisture content of $8 \%$ and feeding weight $100 \mathrm{gm}$.

\section{REFERENCES}

ASTM C618. Standard specification for coal fly ash and raw or calcined natural pozzolan for use as a mineral admixture in concrete. Annual Book of ASTM Standards. Philadelphia, USA; 1993.

Balasubramanian, S., R. Sharma and S. R. Vijay Kumar. 2011. Effect of moisture content and feeding weighton size reduction of pearl millet. Journal of Food Science and Engineering, 1: $93-99$

Central Agency for Public Mobilization and statistics (CAPMAS), 2018. Spaces crop and plant production. Bulletin, Jan. 2018/71-22122-2016.

Fitzpatrick, J. J., T. Iqbal, C. Delaney, T. Twomey, and M. K. Keogh. 2004. Flow property measurement of food powders and sensitivity of Jenike's hopper design methodology to the measured values. J. Food Eng. 61(3): 399-405.

Gu H., Zhang J., Bao J. 2014. Inhibitor analysis and adaptive evolution of Saccharomyces cerevisiae for simultaneous saccharification and ethanol fermentation from industrial waste corn cobscob residues. Bioresour. Technol. 157, 6-13.

Guntoro, S. 2009. Mengolah tongkol jagung. http://www.bisnisbali.com2009/06/05/newsopini/g.htm. Diakses pada tanggal 27 Februari 2013 Makassar.

Kurt, G. (1979): Engineering formulas . 3rd. Ed. Mc Graw - Hill book Co.

Mani, S., L. G. Tabil, and S. Sokhansanj. 2004. Grinding performance and physical properties of wheat and barley straws, corn stover, and switchgrass. Biomass and Bioenergy 27(4): 339-352. 
Manlu, Y. U., A. R. Womac, and L. O. Pordesimo. 2003. Review of biomass size reduction technology. ASAE Paper No. 036077. St. Joseph, Mich.: ASAE

Morad, M.M. M.,A. Aranout, O.A. Omar and H.I. Ahmed (2007): Effect of mechanical chopping and adding different farm residues on soil physical properties and wheat yield. Zagazig J. Agric. Res., 34 (4): 781-804.

Nilai Nutrisi Tongkol Jagung: Komposisi Kimia dan Kecernaan In Vitro. JITV Vol. 17 No $1: 60-64$.

Perry, R. H. and D. Green. 1984. Perry's chemical engineers' handbook (5th ed). New York: McGraw-Hill Book Company.

Probst, K. V. ;R. P. Kingsly Ambrose, R. L. Pinto, R. Bali, P. Krishnakumar, K. E. Ileleji Transactions of the ASAE. American Society of Agricultural Engineers · January 2013

Singh, A. K., M. Srivastava, N. K. Rajneesh and S. Shukla,. Corncobs as Low Cost Bio-Adsorbent for Water and Waste Water Treatment. International Journal of Innovative Research in Science, Engineering and Technology. Vol. 6, Issue 10, October 2017.

Suthar, S. H. and Das, S. K., Some physical properties of karingda seeds. Journal of Agricultural Engineering Research, 65(1), 15-22, 1996.

Tampoebolon, M.P., 1996. Protozoologi. Pusat Antar Universitas Ilmu Hayat Institut Pertanian Bogor. hlm 116 - 118.

Tsai W T, Chang C Y, Wang S Y, Chang C F, Chien S F and Sun H F, Cleaner production of carbon adsorbents by utilizing agricultural waste corn cob. Res. Conserv. Recycl, 32 (2001) 43-53.

Velu, V., A. Nagender, P. G. Prabhakara Rao and D. G. Rao. 2006. Dry milling characteristic of microwave dried maize grains. Journal of Food Engineering 74, 30- 36.

Zhou, B., K. Ileleji, and G. Ejeta. 2008. Physical property relationships of bulk corn cobs stover particles. Trans. ASABE 51(2): 581-590. 


\section{الملخص العربي \\ الطدن الاقيق لقوالح الذرة لاستخد/مها كمواد ماصة للماء. د/ هيثم حسين يوسف محمد' و د د/محد أبراهيم نصر مرسي}

تعتبر كوالح الذرة من أهم المخلفات الناتجة من زراعة الذرة والتي تسبب العديد من المشاكل

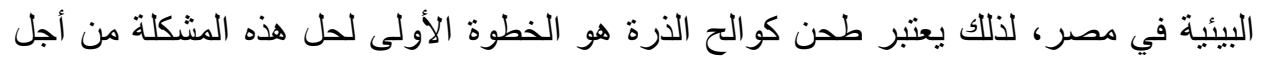
استخدامها كمو اد خام في العديد من الصناعات.

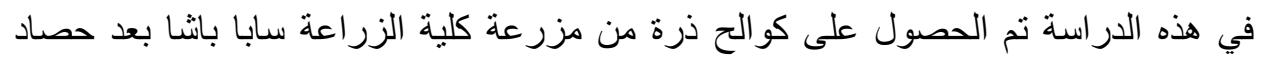

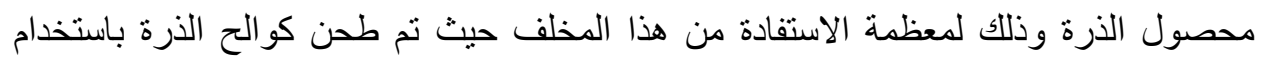

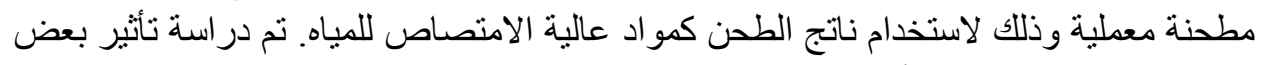

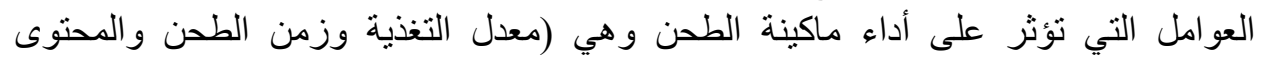

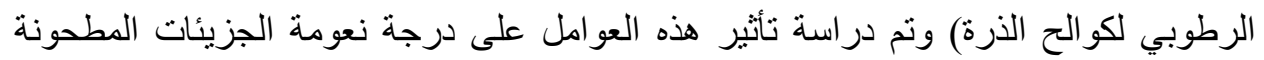

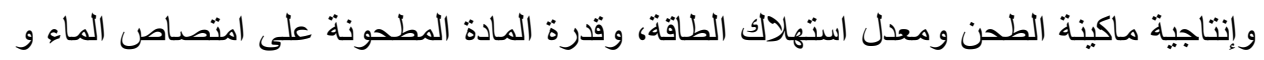

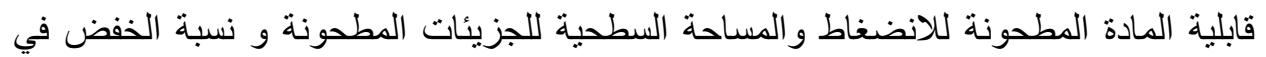

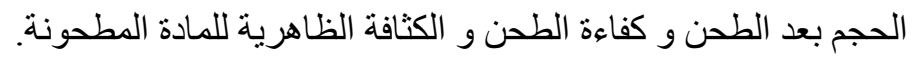

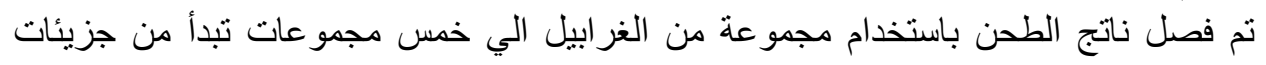

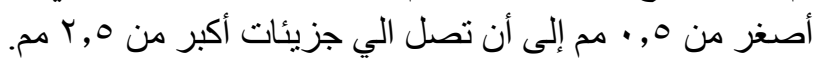

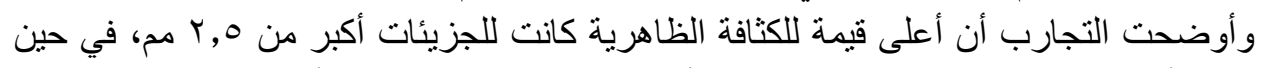

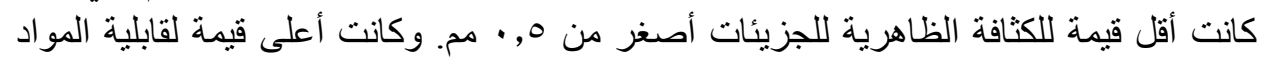

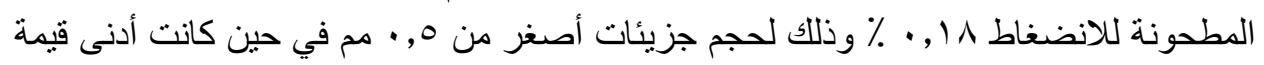

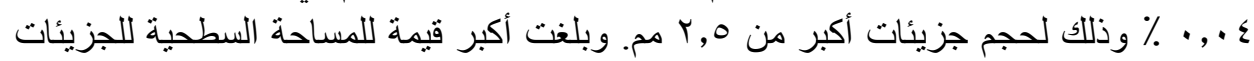

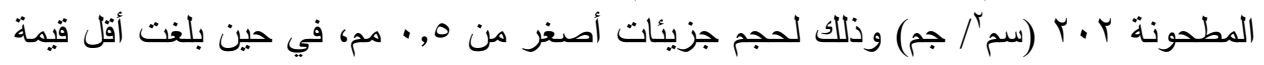

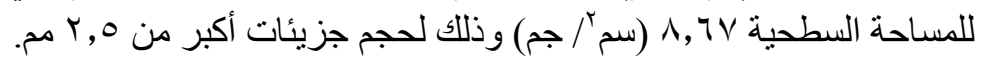

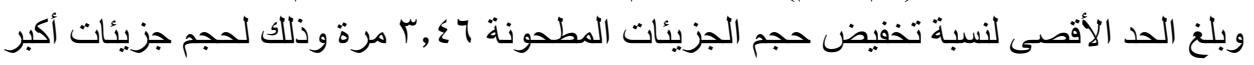

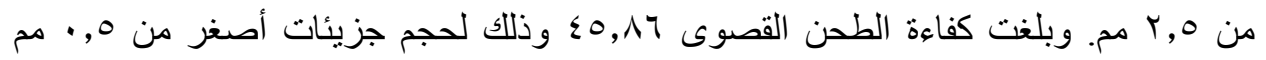

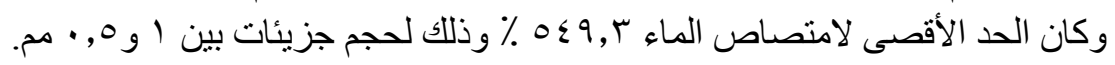

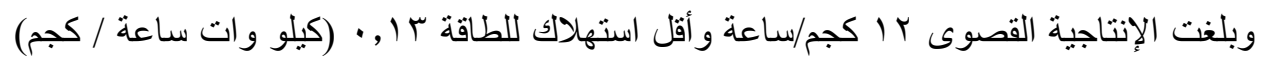

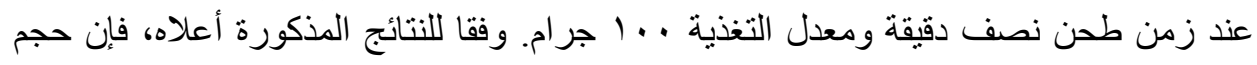

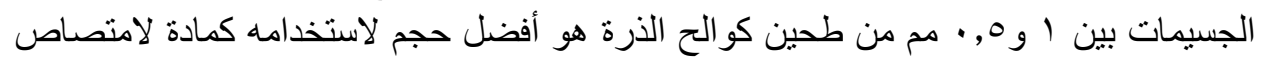

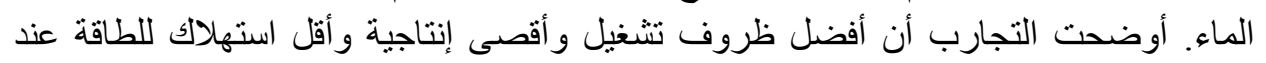

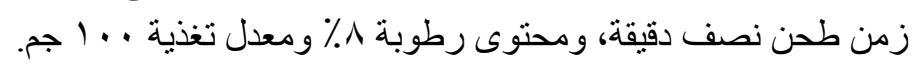

1 - مدرس- قسم الأراضي و الكيمياء الزراعية، كلية زراعة سابا باثنا، جامعة الإسكندرية، مصر. r - مدرس- قسم الهندسة الزراعية، كلية زراعة الثاطبي، جامعة الإسكندرية، مصر. 